УДК 342.924

\title{
ОНОВЛЕНИЙ ВАРІАНТ ПРОЕКТУ ЗАКОНУ УКРАЇНИ «ПРО АДМІНІСТРАТИВНУ ПРОЦЕДУРУ»
}

\author{
А. Школик \\ Львівський національний університет імені Івана Франка, \\ вул. Університетська, 1, Львів, Україна, 79000, \\ e-mail:a.shkolyk@gmail.com
}

Охарактеризовано черговий варіант проекту основоположного акта адміністративного законодавства - Закону України «Про адміністративну процедуру», який було подано Кабінетом Міністрів України та зареєстровано у Верховній Раді України у травні 2020 року. З'ясовано основні новації офіційного законопроекту порівняно з його попередніми версіями щодо концептуальних питань: предмета правового регулювання і сфери дії, включаючи проблематику співвідношення з актами спеціального законодавства, а також загальної структури законопроекту. Також у дослідженні описано окремі адміністративно-процедурні норми, що було додано або вилучено в оновленому варіанті.

В результаті проведеного аналізу виявлено як позитивні, так і не надто виправдані новації в останньому офріційному законопроекті. Зокрема, зроблено висновок, що найістотнішим недоліком $€$ подальша відсутність чіткого визначення майбутньої сфери дії цього загального законодавчого акта та його співвідношення з актами спеціального законодавства. Для усунення цього недоліку запропоновано уже в перших статтях законопроекту перерахувати ссрери публічного адміністрування, на які цей акт не поширюватиметься або ж назвати законодавчі акти, у яких діятимуть спеціальні адміністративно-процедурні норми.

Підтримано більшість із передбачених у законопроекті нових юридичних норм щодо впровадження в публічне адміністрування цифррових електронних технологій, однак вказано, що їх розміщення у тексті законопроекту потребує системної переробки з метою логічного та послідовного викладу.

Також з'ясовано, що позитивні доповнення в частині узгодження інших законодавчих актів із нормами майбутнього Закону України «Про адміністративну процедуру» $є$ недостатніми. У цьому контексті запропоновано, щоб Закон України «Про звернення громадян» загалом втратив чинність, а замість нього розробити та ухвалити Закон України «Про петиції», поряд із аналізованим адміністративно-процедурним актом.

Ключові слова: удосконалення законопроекту, загальний акт про адміністративну процедуру, узгодження законодавчих актів.

\section{DOI: http://dx.doi.org/10.30970/vla.2019.69.129}

Понад двадцятирічну історію розроблення та доопрацювання базового акта адміністративного законодавства - загального закону (кодексу) про адміністративну процедуру - нещодавно було продовжено. У середині травня поточного року чинний Кабінет Міністрів України формально схвалив черговий варіант проекту Закону України «Про адміністративну процедуру», який відразу ж було зареєстровано у Верховній Раді України [3]. Оновлений варіант законопроекту по суті замінив його попередню версію, яку пропонував понад рік тому [2] тогочасний Уряд України і згодом відкликав цей же орган у наступному складі. Оскільки оновлена редакція цього багатостраждального законопроекту стала відомою широкому загалу лише з моментом іiі офіційного опублікування на сайті Верховної

(C) Школик А., 2020 
Ради України, варто з'ясувати, чи зазнав він істотних змін порівняно 3 попередньою версією, та охарактеризувати такі зміни.

Таке з'ясування вважаємо важливим з огляду на підвищений науковий інтерес до тематики адміністративної процедури серед вітчизняних адміністративістів останніми роками. Попередній, не схвалений парламентом проект Закону України «Про адміністративну процедуру» чи не вперше в історії української адміністративно-правової науки став предметом опублікованого науково-практичного коментаря [1]. До написання цього коментаря було залучено частину розробників законопроекту, а також відомих у галузі адміністративного права науковців та практиків: О. Ф. Андрійко, В. М. Бевзенка, Т. О. Гуржія, О. М. Каменчука, Л. Є. Кисіль, Р. О. Куйбіду, В. Г. Перепелюка, А. Л. Петрицького, Н. Г. Плахотнюк, Г. В. Рижкова, М. І. Смоковича, В. П. Тимощука та автора цих рядків. Однак поява оновленого варіанту проекту Закону України «Про адміністративну процедуру» зумовлює необхідність проведення юридичного аналізу саме його.

У своєму дослідженні поставимо завдання описати запропоновані в останньому офіційному варіанті законопроекту новації за такими напрямами:

- предмет регулювання і сфера дії майбутнього закону, а також співвідношення із актами спеціального законодавства;

- загальна структура законопроекту та іiі складові частини;

- окремі адміністративно-процедурні норми, що було додано або вилучено.

До цього додамо, що публікацію призначено для усіх фахівців з адміністративного та адміністративно-процесуального права, які ознайомлені зі змістом попередніх проектів українського загального закону (кодексу) про адміністративну процедуру, принаймні пропонованих останніми роками. Інакше кажучи, будемо намагатися не повторювати відомі зацікавленим адміністративно-процедурною тематикою особам положення.

Предмет правового регулювання в оновленому законопроекті не надто змінився й охоплює порядок прийняття, оскарження в адміністративному порядку та виконання індивідуальних рішень суб'єктів публічного адміністрування, які названо адміністративними актами. Тобто, інші форми (інструменти) публічного адміністрування й надалі залишаються неврегульованими, хоча й на них («іншу адміністративну діяльність адміністративних органів») поширюються визначені в законопроекті загальні принципи адміністративної процедури. Коло закріплених винятків 3 дії майбутнього закону також не змінилося порівняно 3 попереднім варіантом і дає загальне уявлення про відносини, на які він не поширюється.

I надалі законопроект допускає можливість правового регулювання особливостей адміністративного провадження в актах спеціального законодавства (окремих категоріях справ), при тому не визначаючи, про які справи, сфери публічного адміністрування чи просто законодавчі акти йдеться. Такий підхід допоможе практично кожному міністерству лобіювати ухвалення спеціального законодавства iз вмістом адміністративно-процедурних норм для відповідної сфери, що без сумніву нівелюватиме роль і значення загального закону (кодексу) в майбутньому.

Також із законопроекту вилучено згадку про рамкові Закони України «Про адміністративні послуги» та «Про основи державного нагляду (контролю) у сфері господарської діяльності», що в принципі варто визнати слушним. Адже ці законодавчі акти також регулюють адміністративну процедуру на сучасному етапі і при ухваленні загального закону (кодексу) треба було б чітко розмежувати сфери їх застосування. Однак якщо в оновленому варіанті «Прикінцевих та перехідних положень» законопроекту вилученню адміністративно-процедурних норм із Закону України «Про адміністративні послуги» присвячено низку пунктів, то щодо поло- 
жень Закону України «Про основи державного нагляду (контролю) у сфері господарської діяльності» там не знаходимо жодної згадки. Такий вибірковий підхід до упорядкування чинного законодавства України навряд чи можна виправдати: у другому 3 названих Законів міститься чимало адміністративно-процедурних норм, що регулюють інспекційну (контрольно-наглядову) діяльність публічної адміністрації. Своєю чергою загальний закон (кодекс) про адміністративну процедуру також регулюватиме інспекційні (контрольно-наглядові) провадження, і колізій у правозастосуванні без чіткого розмежування норм обох законодавчих актів не уникнути.

У зв'язку зі збереженим предметом правового регулювання, не зазнала значних змін і загальна структура проекту Закону України «Про адміністративну процедуру». Єдиний істотний виняток становить вилучення наявного у попередньому варіанті розділу III «Дослідження обставин справи, докази, строки адміністративного провадження». Частково модифіковане регулювання цих питань було розпорошене до оновлених розділів II «Адміністративний орган, учасники адміністративного провадження та особи, які сприяють розгляду справи», III «Адміністративне провадження» та зовсім нового розділу VIII «Строки та офіційне засвідчення в адміністративному провадженні». На нашу думку, таку диверсифікацію адміністративно-процедурних норм можна виправдати у частині їх переміщення до існуючих розділів II та III. Проте додавання наприкінці законопроекту окремого нового розділу VIII із правовим регулюванням двох специфічних аспектів адміністративного провадження руйнує його попередню логічну структуру, не надто відповідає усталеним підходам до формування процесуальних кодексів, а тому не може бути нами підтримане.

Інші складові структури проекту Закону України «Про адміністративну процедуру було залишено без глобальних змін, хоча змістовне наповнення багатьох статей - оновлене, на чому зупинимося детальніше.

1. У контексті впровадження електронних цифрових технологій до публічного адміністрування, присвячену посадовій особі адміністративного органу статтю 22 доповнено пунктом 3, в якому передбачено можливість здійснення адміністративного провадження в автоматичному режимі, за допомогою програмних засобів без втручання людини. По суті пропонована редакція норми має здебільшого орієнтуюче значення для правозастосування, відсилаючи до актів спеціального законодавства. Крім того, зміст пункту 3 не відповідає назві самої статті «Посадова особа адміністративного органу», яку варто переформулювати у разі збереження названого пункту саме у цій статті законопроекту.

2. Цілком новою в останньому законопроекті є окрема стаття 27 про адміністративну взаємодопомогу. Пропоновані тут норми передбачають правове регулювання внутрішніх відносин між уповноваженими суб' єктами публічного адміністрування, однак при тому безпосередньо пов'язаних зі зовнішньою адміністративною процедурою: щодо вчинення іншим уповноваженим суб'єктом окремих дій. Загалом варто підтримати впровадження таких норм, зважаючи на потреби практики, а також - на останні напрацювання адміністративно-правової доктрини. Адже в Модельних правилах про адміністративну процедуру Європейського Союзу наявна окрема книга про взаємодопомогу між суб'єктами публічної влади [5, с. 198-231], тож пропоновану статтю навіть варто розширити. 3. Достатньо цікава новація оновленої версії законопроекту міститься у пункті 3 статті 42 про «неприйнятні» заяви. Підставами вважати заяву приватної особи неприйнятною можуть бути достатньо різні обставини:

- в ній не викладено змісту вимоги заявника або такі вимоги є очевидно безпідставними; 
- у заяві застосовано ненормативну лексику;

- заява містить заклики до розпалювання національної, расової, релігійної ворожнечі.

Далі в аналізованій нормі визначено, що після отримання такої заяви суб'єкт публічного адміністрування (адміністративний орган) пропонує виправити недоліки приватній особі у встановлений строк і повідомляє ії про правові наслідки невиправлення вказаних недоліків. Пропонована норма, на нашу думку, об'єднує надто різні: логічні, лінгвістичні та юридичні підстави, а тому їх варто розділити. Крім того, правове регулювання тут чималою мірою нагадує інститут залишення заяви без руху i доцільніше було б принаймні частково імплементувати реалізацію ідеї неприйнятності заяви до відповідної, спеціально призначеної статті 40 законопроекту.

4. Серед положень законопроекту, що зазнали істотних змін та доповнень, виділимо також статтю 51 останньої редакції «Пояснення та зауваження учасників адміністративного провадження». Передусім зазначимо недоцільне, на нашу думку, вилучення норми про те, що «неподання чи несвоєчасне подання адресатом або заінтересованою особою пояснень зауважень у справі може бути підставою для відмови в задоволенні скарги у разі оскарження адміністративного акта» [2]. Ця норма мала стимулюючий характер для учасників адміністративного провадження на стадії адміністративного оскарження і була спрямована на ефективне вирішення справи та недопущення «приховування важливої для справи інформації [1, с. 286].

Поряд із цим, названу статтю 51 було доповнено новим пунктом 4, у якому передбачено можливість участі в адміністративному провадженні у режимі відеоконференції. Загалом варто позитивно оцінити таку новацію, спрямовану на реалізацію сучасного тренду до e-administration, проте розміщення цієї загальної норми про спосіб розгляду справи у статті про пояснення та зауваження учасників адміністративного провадження, не вважаємо найкращим.

5. Також у контексті названого вище тренду до електронного адміністрування необхідно згадати доповнення законопроекту новим пунктом у статті 65 про можливість прийняття рішення в автоматичному режимі «на підставі електронних документів у машинозчитувальному форматі та/або даних національних електронних інформаційних ресурсів». Більше того, у наступній статті 66 законопроекту прийняття адміністративного акта в «електронній формі в машинозчитувальному форматі» фактично визнано основним варіантом письмової форми, якщо інше не встановлено спеціальним законодавством. Загалом варто підтримати такий підхід, хоча й із вилученням словосполучення «у машинозчитувальному форматі», у якому відчувається лексика з попереднього століття.

Поряд із цим звернемо увагу на збереження термінологічної плутанини, яку збережено у названих статтях також і в останній редакції законопроекту. Поперше, статтю 65 названо «прийняття рішення у справі», а уже в пункті першому йдеться про прийняття адміністративного акта». По-друге, у пропонованому пункті третьому знову використано сумнівну конструкцію «юридично значимої дії», яка перекочувала сюди із радянської адміністративно-правової доктрини. В будь-якому випадку, проблему тут закладено ще на початку законопроекту, коли адміністративним актом було названо рішення індивідуальної дії і таким способом заплутано наступне правове регулювання.

6. У частині регулювання стадії адміністративного оскарження законопроект також містить доповнення стосовно можливості подання скарги в електронній формі і навіть без електронного підпису за умови автентифікації приватної особи. Однак посилання у цій статті на використання Єдиного державного веб-порталу електронних послуг виглядає, як мінімум, дивним з огляду на оскарження не лише рішень, дій чи бездіяльності уповноважених суб’єктів щодо надання адміністра- 
тивних послуг, але й вчинених під час інспекційної (контрольної, наглядової) діяльності публічної адміністрації.

Проте основним недоліком оновленого розділу про стадію адміністративного оскарження, що залишився із попереднього варіанту законопроекту, на нашу думку, $є$ відсутність врегулювання питання про співвідношення між адміністративним та судовим способами захисту порушених прав приватних осіб. Тут доречно пригадати, що у законодавстві багатьох держав-членів Європейського Союзу подання скарги в адміністративному порядку є обов'язковою передумовою звернення до суду, принаймні у певних сферах публічного адміністрування. Також звернемо увагу, що і в українському законодавстві є приклад закріплення чіткого пріоритету судового оскарження перед адміністративним. Відповідно до норми Податкового кодексу України, оскаржене в судовому порядку рішення контролюючого органу, не підлягає адміністративному оскарженню [4].

7. Останній пункт огляду основних новацій останнього варіанту проекту Закону України «Про адміністративну процедуру» стосується його «Прикінцевих та перехідних положень».

Найістотнішим позитивним моментом уважаємо уже згадуване приведення у відповідність адміністративно-процедурних норм Закону України «Про адміністративні послуги» із майбутніми положеннями аналізованого нами законопроекту. Фактично переважну більшість цих норм зі статей 9 та 10 пропонується вилучити, при тому залишивши достатньо нейтральні речення. На наш погляд, зазначені статті Закону України «Про адміністративні послуги» можна вилучити цілком, щоб у суб'єктів законодавчої ініціативи з часом не виникало бажання їх доповнити певними особливостями.

Поряд із цим у «Прикінцевих та перехідних положеннях» запропоновано врегулювати співвідношення між майбутнім Законом «Про адміністративну процедуру» та чинним загальним Законом України «Про звернення громадян», закріпивши пріоритет застосування адміністративно-процедурного акта при вирішенні «питань, порушених у заявах (клопотаннях) і скаргах громадян». Спрямування такого підходу розробників уважаємо правильним, однак недостатнім. Залишення в силі адміністративно-процедурних норм Закону України «Про звернення громадян» спричинятиме спокусу для уповноважених суб'єктів публічного адміністрування застосувати саме їх в окремих ситуаціях, що навряд чи сприятиме правовій визначеності для приватних осіб. Тому наша позиція є більш радикальною та полягає у втраті чинності цим дещо застарілим законодавчим актом. Замість нього доцільно ухвалити окремий Закон «Про петиції» (в частині регулювання існуючих пропозицій) та, відповідно, Закон «Про адміністративну процедуру» (стосовно регулювання заяв та скарг, хоч і не обмежуючись ними). Звичайно, що така позиція потребує додаткової законопроектної роботи, але чітке розмежування предмета правового регулювання між законодавчими актами усуває можливість вибіркового застосування їхніх норм.

Підсумовуючи цей короткий огляд оновленого варіанту проекту Закону України «Про адміністративну процедуру», доходимо наступних висновків.

По-перше, концептуально остання версія законопроекту не зазнала значних змін: це стосується предмета правового регулювання, сфери дії законодавчого акта і загальної структури. Найважливішим недоліком у цьому контексті вважаємо відсутність чіткого визначення майбутньої сфери дії цього загального законодавчого акта та його співвідношення з актами спеціального законодавства. Для усунення цього недоліку необхідно вже у перших статтях законопроекту перерахувати сфери 
публічного адміністрування, на які цей акт не поширюватиметься або ж назвати законодавчі акти, в яких діятимуть спеціальні адміністративно-процедурні норми.

По-друге, законопроект обгрунтовано доповнено низкою нових норм, спрямованих на впровадження цифрових електронних технологій в публічному адмініструванні. Підтримуючи більшість із пропонованих у цьому напрямі новацій, зазначимо, що їх розміщення у тексті законопроекту не завжди відповідає усталеній та логічній побудові процесуальних та процедурних кодифікованих актів і потребує системної переробки.

По-третє, в оновленому законопроекті зроблено крок у напрямі погодження інших законодавчих актів (зокрема, Закону України «Про адміністративні послуги»), 3 нормами майбутнього загального закону (кодексу) про адміністративну процедуру. Однак загалом законопроект залишається слабко узгодженим з іншими актами законодавства України, що залишаться чинними у пропонованому варіанті. В цьому контексті наша позиція передбачає доцільність радикальніших змін до чинного законодавства i, зокрема, втрату чинності Законом України «Про звернення громадян» та ухвалення поряд із аналізованим адміністративно-процедурним актом також Закону України «Про петиції».

У результаті виявлення зазначених недоліків оновленого варіанту проекту Закону України «Про адміністративну процедуру», не викликає сумніву доцільність учергове доопрацювати його зміст перед остаточним ухваленням, із врахуванням викладених зауважень.

\section{Список використаних джерел}

1. Науково-практичний коментар до проекту Закону України «Про адміністративну процедуру» / за заг. ред. В. П. Тимощука. Київ: Мишалов, 2019. 460 с.

2. Про адміністративну процедуру: Проект Закону України від 28 грудня 2018 року № 9456. URL: http://w1.c1.rada.gov.ua/pls/zweb2/webproc4_1?pf3511=65307.

3. Про адміністративну процедуру: Проект Закону України від 14 травня 2020 року № 3745. URL: http://w1.c1.rada.gov.ua/pls/zweb2/webproc4_1?pf3511=68834.

4. Податковий кодекс України від 04.12.2010 p. Пункт 56.18. URL: https://zakon.rada.gov.ua/laws/show/2755-17.

5. ReNEUAL Model Rules on EU Administrative Procedure. Book V Mutual assistance / Edited by Herwig C. H. Hofmann, Jens-Peter Schneider and Jacques Ziller. Version for on-line publication, 2014. URL: http://www.reneual.eu/images/Home/ReNEUAL-Model_RulesCompilation_BooksI_VI_2014-09-03.pdf.

\section{References}

1. Naukovo-praktychnyi komentar do proektu Zakonu Ukrayiny «Pro administratyvnu protseduru» / Za zah. red. V. Tymoshchuka. Kyiv: Myshalov, 2019. $460 \mathrm{~s}$.

2. Pro administratyvnu protseduru: Proekt Zakon Ukrayiny vid 28 hrudnia 2018 roku № 9456. Retrieved from http://w1.c1.rada.gov.ua/pls/zweb2/webproc4_1?pf3511=65307

3. Pro administratyvnu protseduru: Proekt Zakon Ukrayiny vid 14 travnia 2020 roku № 3745. Retrieved from http://w1.c1.rada.gov.ua/pls/zweb2/webproc4_1?pf3511=68834.

4. Podatkovyi kodeks Ukrayiny vid 04 hrudnia 2010 roku. Punkt 56.18. Retrieved from https://zakon.rada.gov.ua/laws/show/2755-17.

5. ReNEUAL Model Rules on EU Administrative Procedure. Book V Mutual assistance / Edited by Herwig C. H. Hofmann, Jens-Peter Schneider and Jacques Ziller. Version for on-line publication, 2014. Retrieved from http://www.reneual.eu/images/Home/ReNEUAL-Model_Rules-Compilation_BooksI_VI_2014-09-03.pdf. 


\title{
THE UPDATED VERSION OF THE DRAFT LAW OF UKRAINE ON ADMINISTRATIVE PROCEDURE
}

\author{
A. Shkolyk \\ Ivan Franko National University of Lviv, \\ 1, Universytetska Str., Lviv, Ukraine, 79000, \\ e-mail: a.shkolyk@gmail.com
}

The article describes another version of the draft basic act of administrative legislation the Law of Ukraine "On Administrative Procedure", which was submitted by the Cabinet of Ministers of Ukraine and registered in the Verkhovna Rada of Ukraine in May 2020.

The task of the research is to clarify the main innovations of the official draft law compared to its previous versions on conceptual issues: the subject matter of legal regulation and its scope, including the relationship with special legislation, as well as the general structure of the draft law. In addition, the study describes some specific administrative procedural rules that have been added or removed in the updated version.

The analysis reveals both positive and poorly justified innovations in the latest official draft law. In particular, it is concluded that the most significant shortcoming is the further lack of a clear definition of the future scope of this general legislative act and its relationship with acts of special legislation. To eliminate this shortcoming, it is proposed to list the areas of public administration to which this act will not apply, or to name the legislative acts in which special administrative procedural rules will apply. It should be done already in the first articles of the draft law.

The updated draft law has been substantially supplemented by a number of new legal norms aimed at the introduction of digital electronic technologies in public administration. While supporting most of the proposed innovations in this direction, it is noted that their placement in the text of the draft law does not always correspond to the established and logical construction of procedural codified acts and requires systematic revision.

It is also clarified that the updated draft law took a step towards harmonizing other legislative acts (in particular, the Law of Ukraine "On Administrative Services") with the norms of the future general law (code) on administrative procedure. However, in general, the draft law remains poorly aligned with other acts of Ukrainian legislation that will remain in force. In this context, more radical changes to the current legislation are supported, and, in particular, the complete repeal of the Law of Ukraine "On Citizens' Appeals" and the adoption of the Law of Ukraine "On Petitions" along with the analyzed act on administrative procedure.

As a result of identifying these and the other shortcomings of the updated version of the draft Law of Ukraine "On Administrative Procedure", there is no doubt expediency to finalize its content once again before final adoption.

Keywords: improvement of the draft law, general act on administrative procedure, harmonizing of legislative acts. 